\title{
Analysis of The Effect of Unit Features, Corporate Factors, Switching Barriers, and Customer Satisfaction Dimensions to Customer Loyalty in Komatsu Forklift Customers in PT. Bina Pertiwi in East Java Area
}

\author{
Muhammad Wahyudi Ari Nugraha ${ }^{\mathrm{a} *}$, Amelia $^{\mathrm{b}}$, Ronald $^{\mathrm{c}}$ \\ amwahyudiarin@gmail.com \\ ${ }^{a}$ Master of Management Student at Pelita Harapan University, Surabaya 60234, Indonesia \\ ${ }^{b, c}$ The Lecturer of Master of Management at Pelita Harapan University, Surabaya 60234, Indonesia
}

\begin{abstract}
Nowadays, technology has become a basic need of people's life, so that every person or organization uses technology in various aspects of their life, including in helping their work. Human need for technology is also supported by rapid development of science and technology, therefore it is now called the technological era. For example with the need for lifting equipment to help human activities, especially in the industrial sector, which previously done by human labor, this has been done with the help of tools, commonly known as forklifts. The type of forklift that was invented for the first time was a hand truck. Forklifts are vehicles that have a function as a means of transport to move goods with a large load capacity. East Java is one of the important areas for industrial development in Indonesia. This study is aimed at analyzing the influence of the unit features dimensions (functions, usability, design, application, and price), corporate factors (customer support and corporate image), switching barriers, and customer satisfaction on customer loyalty to Komatsu Forklift customers at PT. Bina Pertiwi in the East Java area. The sample used in this study is based on data from 105 male and female respondents, domiciled in East Java, with an age limit of 18-60 years. Processing and analyzing data in this research is using SPSS as a software, where analysis statistical product and service solutions (SPSS) is using software 22.0 to process data. Next, tabulate the research results of the respondents, as well as test the research model using Simple Regression and Multiple Regression. The empirical findings indicate that the relationship functions have a significant effect on customer satisfaction with a regression coefficient of 0.212 ; usability has a significant effect on customer satisfaction with a regression coefficient of 0.236 ; applications have a significant effect on customer satisfaction with a regression coefficient of 0.262 ; customer support has a significant effect on customer satisfaction with a regression coefficient of 0.252 ; unit features have a significant effect on customer satisfaction with a regression coefficient of 0.538 ; corporate factors have a significant effect on customer satisfaction with a regression coefficient of 0.378 ; customer satisfaction has a significant effect on customer loyalty with a regression coefficient of 0.533 ; switching cost has a significant effect on customer loyalty with a regression coefficient of 0.298 .
\end{abstract}

Keywords: Unit features, Functions, Usability, Design, Application, Price, Corporate factors, Customer Support, Corporate Image, Switching Barriers, Customer Satisfaction, Customer Loyalty, Forklift, Material Handling.

\section{Introduction}

A forklift is a vehicle that has a special function as a means of transport in moving goods with a large load capacity. Because of its function in such a way, this tool is often used by companies or factories to support the production process. This tool can be operated both indoors and outdoors, such as loading and unloading goods at ports, warehouses, factories, shops, expeditions, supermarkets and many more. The 
operation method is quite easy, especially the forklift already uses full electric so that it can be done easily to raise or lower the load and maneuver a long distance, namely the operator sits on the operator's cabin that has been provided and various features are provided, including a digital LCD screen, multi-functions, speed control buttons, alarms, automatic brakes, seat belts, and others. The use of this forklift is very helpful because besides being able to save on operational costs, work productivity will also increase significantly. What's more, this tool is very environmentally friendly and non-polluting, and even has a sophisticated battery management system to optimize battery life and waste disposal. For the capacity of the forklift itself, usually in general it ranges from 1 ton to 10 ton with the lifting capacity of each unit being able to reach up to a height of 3 meters to 6 meters (kompasiana.com, downloaded on May 17, 2020).

In 2014, the global forklift sales volume exceeded one million units for the first time, and the figure has increased by $7.5 \%$ from the previous year (prnewswire.com, downloaded on 17 May 2020). The increase in export and import activities between continents and countries is one of the factors driving the growth of the global forklift market. The increasing global demand for consumer goods as well as the rapid growth of ecommerce businesses around the world (especially in developing countries) has resulted in increased activity at container ports which has boosted demand for forklifts at ports and airports for handling goods. In 2015, the volume of global container ports reached 700 million TEU (Twenty Foot Equivalent) of which e-commerce shipments accounted for $63.2 \%$ of all shipments, up $1.8 \%$ from 2014 . Developing countries such as India, China and Mexico has seen an increase in industrialization and economic growth, adding to the need for warehouses as well as cargo handling equipment. The construction industry has also seen an increase in the number of forklifts. The increasing demand for forklifts in the construction industry is attributed to the growth in the construction sector which is expected to reach USD 10 trillion by 2020 due to the increasing number of construction projects in developing countries such as China, India, Mexico and the United Arab Emirates. Geographically, the Asia-Pacific region was the largest market for forklifts in 2015 accounting for more than $39 \%$ of the global forklift market share volume. The Asia-Pacific forklift market continues to dominate the market with the increasing number of manufacturing industries and the positive growth of the e-commerce business. The European region is estimated to have the second largest market share, due to the positive outlook for the European economy and favorable increases in trade in goods. Furthermore, the forklift market in the Middle East and Africa is also expected to see positive growth for the forklift market, especially in the construction industry and automotive OEM activities. The North American forklift market is growing significantly as exports and imports of smart devices increase. The US government's free trade policy with Mexico and Brazil is one of the factors that increases car imports from these two countries, so that this activity will spur the growth in demand for forklifts in the region. Forklift sales are expected to grow steadily in the coming years. The market is expected to expand at an annual growth rate of $5.7 \%$ over the forecast period 2017-2030 (goldsteinresearch.com, downloaded 17 May 2020).

The logistics market in Indonesia also affects the demand for forklift units. Based on data from the Central Statistics Agency (BPS), Supply Chain Indonesia (SCI) recorded growth in the logistics sector (transportation and warehousing business fields) in the first quarter of 2020 by $1.27 \%$ (year on year). In the first semester of 2019, the logistics sector grew 5.45\%. With this figure, the logistics sector contributed 5.17\% to the Gross Domestic Product (GDP) in the first quarter of 2020. There was a decrease in contributions compared to the first quarter of 2019 which was recorded at 5.53\% (supplychainindonesia.com, downloaded on 17 May 2020). With the advancement and market growth in the logistics sector, the market demand for changing labor (which previously used manual power) to machines is getting higher, so that forklifts have become one of the most widely used tools for handling materials in the logistics industry. From these facts, of course, will make several forklift manufacturers from around the world move to market their products, including in Indonesia. Of course, each of these brands has their own market segments, characteristics and advantages, one of which is the Komatsu Forklift (source: Internal data of PT. Bina Pertiwi, 2020). 
East Java is one of the important areas for industrial sector in Indonesia. With the large number of industrial areas in East Java, it is certainly one of the reasons why many forklift brands are present in the East Java area to support the operational activities of these companies. Therefore it is important for PT. Bina Pertiwi as the authorized distributor of Komatsu Forklift to increase and grow customer loyalty to customers, because customer loyalty is an important factor for a company. Kotler et al., (2002) stated that there are six reasons why an institution needs to get customer loyalty. First: existing customers are more prospective, meaning that loyal customers will provide great benefits to the institution. Second: the cost of acquiring new customers is much greater than keeping and retaining existing customers. Third: customers who already trust the institution in one business will also trust in other matters. Fourth: the institution's operating costs will be efficient if it has many loyal customers. Fifth: institutions can reduce psychological and social costs because old customers have had many positive experiences with the institution. Sixth: loyal customers will always defend the institution and even try to attract and advise others to become customers. When market growth slows down or markets become more competitive, firms may seek more to maintain market share by focusing on retaining existing customers (Lee et al, 2001).

The first research gap in this study is the effect of the price variable on customer satisfaction, based on the results of previous research conducted by Kim et al., (2016) which states that there is an insignificant relationship between the variable price and customer satisfaction. This study explains that price does not have a significant direct effect on customer satisfaction, it takes an intervening variable, namely value for money, to mediate the effect of price on customer satisfaction. However, this contradicts the results of research conducted by Santouridis and Trivelas (2010) which states that there is a significant relationship between price and customer satisfaction. The second research gap in this study is the influence of customer satisfaction and customer loyalty variables. Based on the results of previous research conducted by Kim et al., (2016) which states that there is a significant relationship between customer satisfaction and customer loyalty variables. This means that if customers feel the benefits and value provided by a company to customers, this will increase satisfaction and make customers loyal to the company. However, this contradicts the results of research conducted by Chen and Tsai (2008), which state that there is an insignificant influence between customer satisfaction and customer loyalty. This is because in Chen and Tsai's (2008) study of customer satisfaction, there are two conditions, namely product shopping services through television and direct product services to customers, causing a biased assessment to identify which sources actually lead to insignificant customer satisfaction relationships and customer loyalty (product shopping services on television channels or the product service itself). Therefore, this study was conducted to ascertain the effect of customer satisfaction on customer loyalty whether it has a significant effect or vice versa on forklift products. For the two research gaps, this research is becoming increasingly interesting to do, namely to ascertain the effect of the price variable on customer satisfaction, and the effect of customer satisfaction on customer loyalty whether it has a significant relationship or vice versa.

This research discusses the factors that influence customer loyalty. To see the factors that affect customer loyalty based on several replicated and compiled journals, we will examine whether functions, usability, design, application, and price (which are included in the unit features dimension), customer support and corporate image (which are included in the corporate factors dimension) towards customer loyalty through customer satisfaction, as well as switching costs towards customer loyalty to Komatsu Forklift customers at PT. Bina Pertiwi in the East Java Area.

\section{Litterature Review}

\subsection{Theories and Hypotheses}




\subsubsection{Functions}

According to Deng et al., (2010) functions refer to the practical or technical benefits that users can get when using a product due to its various functions, thus making someone use it frequently. Meanwhile, according to Sweeney and Soutar (2001), functions are seen as the main influence on consumers when they decide to buy or not to buy a product. In research conducted by Kim et al., (2016), it is stated that there is a significant effect between functions and customer satisfaction. In a study conducted by Deng et al., (2016) stated that there is a significant influence between functions on customer satisfaction.

H1: Functions have a significant effect on customer satisfaction.

\subsubsection{Usability}

Usability is the level of ease of using, learning, and operating on a device (Oghuma, 2016). Usability is a quality attribute that assesses how easy the user interface is to use and also refers to methods to increase ease of use during the design process (Nielsen, 2012). In a study conducted by Kim et al., (2016) stated that there is a significant influence between usability and customer satisfaction. The same thing, also conveyed by Belanche et al., (2012) states that if there is a significant influence between usability on customer satisfaction. H2: Usability has a significant effect on customer satisfaction.

\subsubsection{Design}

According to Tan and Sie (2015) design is the aesthetic quality of a product. Design can affect customer satisfaction, so companies must channel their creativity and innovation to produce attractive designs according to consumer tastes (Kim et al., 2016). In a study conducted by Kim et al., (2016) stated that there is a significant influence between design and customer satisfaction. The same thing, also conveyed by Xu et al., (2015) stated that if there is a significant effect between design on customer satisfaction.

H3: Design has a significant effect on customer satisfaction.

\subsubsection{Application}

According to Buyens (2001) applications are a unit of software designed to serve the needs of several activities. Applications are devices that have been specially designed for mobile platforms (Pressman and Maxim, 2014). In a study conducted by Kim et al., (2016) stated that there is a significant effect between application and customer satisfaction. Applications refers to the various choices of applications available on a product that have a significant effect on customer satisfaction (Xu et al., 2015).

H4: Application has a significant effect on customer satisfaction.

\subsubsection{Price}

According to Yesawich (2004) price is an important strategic variable because it has a direct relationship with company objectives and its interactions with other elements of the marketing mix. Price is the amount of money charged or imposed on a product or service (Simamora, 2003). In research conducted by Lee (2011), it is stated that there is a significant effect between price on customer satisfaction. The same thing, also stated by Xu et al., (2015) stated that if there is a significant effect between price on customer satisfaction.

H5: Price has a significant effect on customer satisfaction. 


\subsubsection{Customer Support}

According to Kim et al., (2014) customer support is a company way of providing assistance to customers when responding to customer needs or complaints. Examples of customer support include providing product or service restoration as part of after-sales service, being responsive to customer inquiries, and paying attention to customer requests promptly. In research conducted by Kim et al., (2016) states that there is a significant influence between customer support and customer satisfaction. The same thing, also stated by Kim et al., (2004) states that if there is a significant influence between customer support on customer satisfaction.

H6: Customer support has a significant effect on customer satisfaction.

\subsubsection{Corporate Image}

Corporate image is an image created and instilled by companies to consumers (Ene and Özkaya, 2014). A company will be seen through its image either negative or positive. A positive image will give a good meaning to the company's products and so can increase the number of sales. On the other hand, sales of a company's products will fall or suffer losses if its image is viewed negatively by society (Yusoff, 1995). In research conducted by Kim et al., (2016) states that there is a significant influence between corporate image and customer satisfaction. The same thing was stated by Lai et al., (2015) if there is a significant influence between corporate image on customer satisfaction.

H7: Corporate image has a significant effect on customer satisfaction.

\subsubsection{Unit Features}

According to Kim et al., (2016) the feature unit consists of functions, usability, application, and price. Unit features are the basic requirements of a device. However, providing many functions does not always fulfill customer satisfaction. For this reason, it is necessary to identify what customers want in using a device, and most importantly to concentrate on meeting basic customer needs (Kim et al., 2016). In a study conducted by Kim et al., (2016), it is stated that there is a significant influence between unit features on customer satisfaction. According to Kim et al., (2016) the feature unit consists of functions, usability, application, and price.

H8: Unit features have a significant effect on customer satisfaction.

\subsubsection{Corporate Factors}

According to Kim et al., (2016) corporate factors consist of customer support and corporate image. At this time a device manufacturer needs to focus on strengthening customer support by responding to customer complaints and providing more after-sales services (Kim et al., 2016). It is very important to show a consumer-friendly, innovative, smart, and customer-oriented corporate image (Kim et al., 2016). In research conducted by Kim et al., (2016) stated that there is a significant influence between corporate factors on customer satisfaction.

H9: Corporate factors have a significant effect on customer satisfaction.

\subsubsection{Customer Satisfaction}

According to Demirgunes (2015) customer satisfaction is a general evaluation of company performance based on the experiences of consumers. Overall customer satisfaction describes the evaluation of consumers from an organization based on all interactions and experiences of consumers with a particular organization (Jones and Suh, 2000). In research conducted by Kim et al., (2016) states that there is a significant influence between 
customer satisfaction and customer loyalty. The same thing was stated by Kim et al., (2015) if there is a significant influence between customer satisfaction and customer loyalty.

H10: Customer satisfaction has a significant effect on customer loyalty.

\subsubsection{Switching Costs}

Switching cost is a category of switching barriers that emerged from an analysis (Colgate and Lang, 2001). Switching costs have been identified as a contributing factor in maintaining relationships (Colgate and Lang, 2001). Switching costs are costs incurred by consumers due to switching to other service providers that will not be experienced if consumers remain loyal to the current service provider (Lee et al., 2001). In research conducted by Kim et al., (2016), it is stated that if there is a significant effect between switching costs on customer loyalty.

H11: Switching costs have a significant effect on customer loyalty.

\subsubsection{Customer loyalty}

Customer loyalty is a positive action that consumers can show to brands, shops, products and activities (Dehghan and Shahin, 2011). According to Kotler and Keller (2009), loyalty is a strongly held commitment to buy again or subscribe to certain products or services in the future even though there are situations and marketing efforts that have the potential to cause behavioral shifts.

\subsection{Research Model}

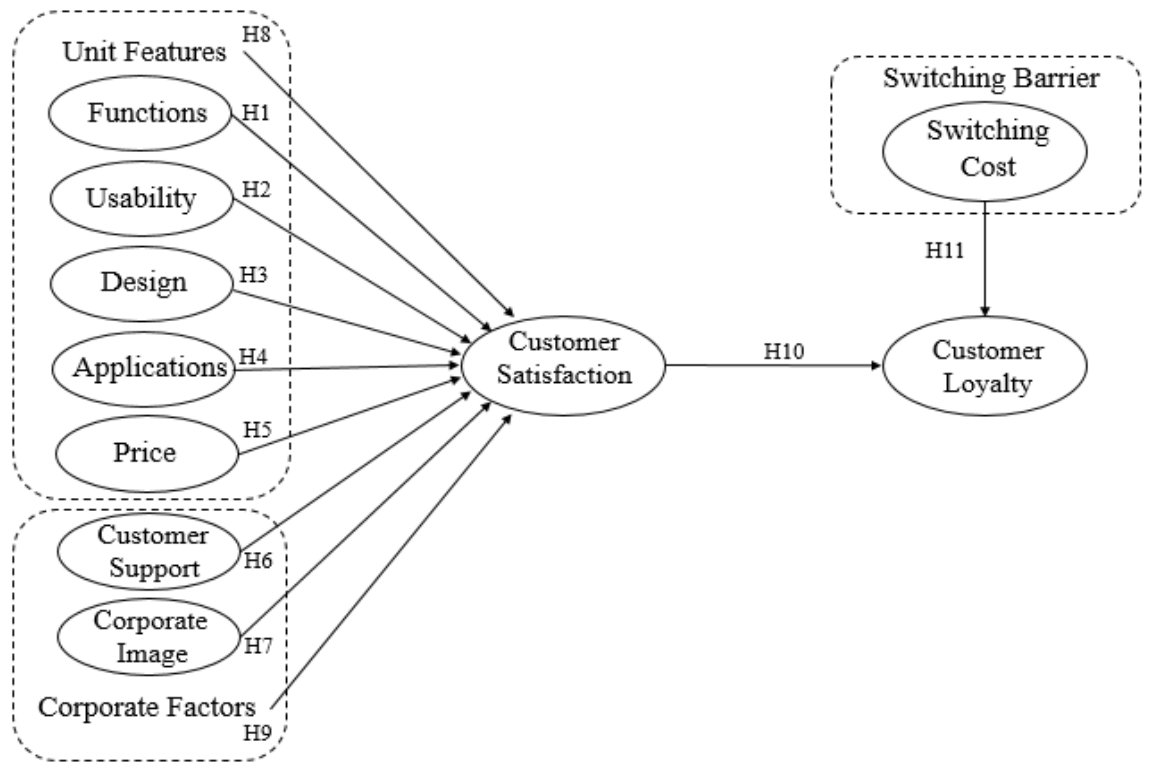

Figure 2.1: The Framework of Research Model 


\section{Research Methods}

The research method used in this research is quantitative method. This research is a causal research, where this research is carried out to develop a pre-existing research model and this research is conducted to test the research hypothesis that has been determined based on literature review to answer the problems identified in the previous chapter. The population that will be used in this study are customers of PT. Bina Pertiwi as the authorized distributor of Komatsu Forklifts in East Java. The sampling method used in this research is probability sampling. This study uses a questionnaire as the main tool in data collection. In this study, researchers will use a full sampling technique (saturated sample), where researchers select respondents who will help researchers to distribute and fill out questionnaires. The application of the full sampling technique in this study was carried out by distributing questionnaires to be distributed to Komatsu Forklift customers who have already made purchases of Komatsu Forklifts at PT. Bina Pertiwi selected as the sample. The area used as a place for distributing questionnaires is the province of East Java, so that the selected respondents are in accordance with what is expected. The number of indicators used in this study is 30 indicators for Komatsu Forklift customer questionnaires. This study will use a sampling method, namely full sampling. The number of samples of 105 is determined based on the company database that currently exists, where 105 customers meet the criteria to be respondents in the study.

\section{Results and Discussion}

\subsection{Assessment of Measurement Model}

Table 4.1: Multiple Regression Effects of Functions, Usability, Design, Applications, Price, Corporate Support, \& Corporate Image to Customer Satisfaction

\begin{tabular}{|c|c|c|c|c|c|c|c|}
\hline \multirow{2}{*}{ Model } & \multicolumn{2}{|c|}{ Unstandardized Coefficients } & \multirow{2}{*}{$\begin{array}{c}\text { Standardized Coefficients } \\
\text { Beta }\end{array}$} & \multirow{2}{*}{$\mathrm{t}$} & \multirow{2}{*}{ Sig. } & \multicolumn{2}{|c|}{ Collinearity Statistics } \\
\hline & $\mathrm{B}$ & Std. Error & & & & Tolerance & VIF \\
\hline 1 (Constant) & .226 & .247 & & .915 & .362 & & \\
\hline FC & .236 & .098 & .212 & 2.404 & .018 & .290 & 3.450 \\
\hline US & .230 & .094 & .236 & 2.457 & .016 & .244 & 4.091 \\
\hline DS & .059 & .092 & .065 & .641 & .523 & .218 & 4.585 \\
\hline AP & .213 & .065 & .262 & 3.274 & .001 & .353 & 2.834 \\
\hline PR & -.016 & .027 & -.030 & -.581 & .563 & .872 & 1.147 \\
\hline CSP & .216 & .081 & .252 & 2.666 & .009 & .253 & 3.955 \\
\hline $\mathrm{CI}$ & .013 & .092 & .015 & .145 & .885 & .201 & 4.982 \\
\hline
\end{tabular}

a. Dependent Variable: CS

Table 4.2: Multiple Regression Unit features, \& Corporate Factors to Customer Satisfaction

\begin{tabular}{|c|c|c|c|c|c|c|c|}
\hline \multirow{2}{*}{ Model } & \multicolumn{2}{|c|}{ Unstandardized Coefficients } & \multirow{2}{*}{$\begin{array}{c}\text { Standardized Coefficients } \\
\text { Beta }\end{array}$} & \multirow{2}{*}{$\mathrm{t}$} & \multirow{2}{*}{ Sig. } & \multicolumn{2}{|c|}{ Collinearity Statistics } \\
\hline & $\mathrm{B}$ & Std. Error & & & & Tolerance & VIF \\
\hline 1 (Constant) & .528 & .253 & & 2.089 & .039 & & \\
\hline UF & .577 & .077 & .538 & 7.542 & .000 & .589 & 1.697 \\
\hline $\mathrm{CF}$ & .338 & .064 & .378 & 5.300 & .000 & .589 & 1.697 \\
\hline
\end{tabular}

a. Dependent Variable: CS 
Table 4.3: Multiple Regression Switching Cost, \& Customer Satisfaction to Customer Loyalty

\begin{tabular}{|c|c|c|c|c|c|c|c|}
\hline \multirow{2}{*}{ Model } & \multicolumn{2}{|c|}{ Unstandardized Coefficients } & \multirow{2}{*}{\begin{tabular}{c|} 
Standardized Coefficients \\
Beta
\end{tabular}} & \multirow{2}{*}{$\mathrm{t}$} & \multirow{2}{*}{ Sig. } & \multicolumn{2}{|c|}{ Collinearity Statistics } \\
\hline & $\mathrm{B}$ & Std. Error & & & & Tolerance & VIF \\
\hline 1 (Constant) & .169 & .424 & & .398 & .691 & & \\
\hline SWC & .190 & .048 & .298 & 3.927 & .000 & .886 & 1.129 \\
\hline $\mathrm{CS}$ & .723 & .103 & .533 & 7.021 & .000 & .886 & 1.129 \\
\hline
\end{tabular}

a. Dependent Variable: CL

Multiple regression test shows the influence of an independent variable on the dependent variable. The condition for a hypothesis is considered significant when the significance level is less than $0.05(\alpha=$ $5 \%)$. So that the results in this study are explained as follows:

\subsection{Hypotheses Testing}

Table 4.4: Summary of Testing Results.

\begin{tabular}{|l|c|}
\hline \multicolumn{1}{|c|}{ Hypotheses } & Analysis \\
\hline H1: Functions have a significant effect on customer satisfaction. & Accepted \\
\hline H2: Usability has a significant effect on customer satisfaction. & Accepted \\
\hline H3: Design has a significant effect on customer satisfaction. & Rejected \\
\hline H4: Application has a significant effect on customer satisfaction. & Accepted \\
\hline H5: Price has a significant effect on customer satisfaction. & Rejected \\
\hline H6: Customer support has a significant effect on customer satisfaction. & Accepted \\
\hline H7: Corporate image has a significant effect on customer satisfaction. & Rejected \\
\hline H8: Unit features have a significant effect on customer satisfaction. & Accepted \\
\hline H9: Corporate factors have a significant effect on customer satisfaction. & Accepted \\
\hline H10: Customer satisfaction has a significant effect on customer loyalty. & Accepted \\
\hline H1: Switching costs have a significant effect on customer loyalty. & Accepted \\
\hline
\end{tabular}

\subsection{Discussion}

\subsubsection{The effect of Function on Customer Satisfaction}

The first hypothesis is that functions have a significant effect on customer satisfaction. This hypothesis is supported by the $t$ test where the significance is 0.018 (above 0.05 ) which indicates that this hypothesis is accepted. The results of this study support previous research conducted by Kim et al., (2016) which states that the higher the value received by customers from each attribute (function), the more satisfied customers are with certain smartphone manufacturers. Functions are practical or technical benefits that can be obtained by users when using a product because of its various functions, thus making someone use it frequently (Deng et al., 2010).

\subsubsection{The effect of Usability on Customer Satisfaction}

The second hypothesis is usability has a significant effect on customer satisfaction. This hypothesis is supported by the $t$ test where the significance is 0.016 (below 0.05 ) which indicates that this hypothesis is accepted. According to Ha and Park (2013), customer satisfaction is greatly influenced by the level of satisfaction they have with smartphone attributes and evaluations when using a smartphone. Customers will make comparisons of the ease of using the product according to their perceptions with their expectations. If 
customers judge that a product can meet or exceed their wants and expectations, it will lead to satisfaction in the minds of customers.

\subsubsection{The effect of Design on Customer Satisfaction}

The third hypothesis is that design has no significant effect on customer satisfaction but has a positive effect. This hypothesis is supported by the t test where the significance is 0.523 (above 0.05 ) which indicates that this hypothesis is rejected. The results of this study do not support previous research conducted by Kim et al., (2016) which states that the higher the value that consumers receive from each of these attributes (design), the more satisfied they are with smartphone manufacturers.

\subsubsection{The effect of Applications on Customer Satisfaction}

The fourth hypothesis is that applications have a significant effect on customer satisfaction. This hypothesis is supported by the test where the significance is 0.001 (below 0.05 ) which indicates that this hypothesis is accepted. The reason this variable is accepted is because customers feel that the Komatsu Forklift has an application that makes it easy for customers to use daily and is useful for customers.

\subsubsection{The effect of Price on customer Satisfaction}

The fifth hypothesis is that price has no significant effect on customer satisfaction and has a negative effect. This hypothesis is supported by the $t$ test where the significance is 0.563 (above 0.05) which indicates that this hypothesis is rejected. The results of this study support previous research conducted by Kim et al., (2016) which states that price does not have a significant effect on customer satisfaction on the smartphone market in Korea.

\subsubsection{The effect of Customer Support on Customer Satisfaction}

The sixth hypothesis is that customer support has a significant effect on customer satisfaction. This hypothesis is supported by the $t$ test where the significance is 0.009 (below 0.05) which indicates that this hypothesis is accepted. The results of this study support research conducted by Kim et al., (2016) which states that the higher the value that consumers receive from each of these attributes (customer support), the more satisfied they are with certain smartphone manufacturers.

\subsubsection{The effect of Corporate Image on customer Satisfaction}

The seventh hypothesis is that corporate image has no significant effect on customer satisfaction but has a positive effect. This hypothesis is supported by the t test where the significance is 0.885 (above 0.05 ) which indicates that this hypothesis is rejected.

\subsubsection{The effect of Unit Features on Customer Satisfaction}

The eighth hypothesis is that unit features have a significant effect on customer satisfaction. Unit features are a combination of variables owned by Komatsu Forklifts, namely functions, usability, design, application, and price. This hypothesis is supported by the t test where the significance is 0.000 (below 0.05) which indicates that this hypothesis is accepted

\subsubsection{The effect of Corporate Factors on Customer Satisfaction}

The ninth hypothesis is that corporate factors have a significant effect on customer satisfaction. Corporate factors are a combination of variables that represent the company, namely customer support and corporate images. This hypothesis is supported by the $t$ test where the significance is 0.000 (below 0.05 ) which indicates that this hypothesis is accepted. 


\subsubsection{The effect of Customer Satisfaction on Customer Loyalty}

The tenth hypothesis is that customer satisfaction has a significant effect on customer loyalty. This hypothesis is supported by the $t$ test where the significance is 0.000 (below 0.05) which indicates that this hypothesis is accepted. From the research results, it is found that customers are satisfied with Komatsu Forklift products, service from PT. Bina Pertiwi as the authorized distributor of Komatsu Forklifts, and quality of Komatsu Forklifts.

\subsubsection{The effect of Switching Cost on Customer Loyalty}

The eleventh hypothesis is that switching costs have a significant effect on customer loyalty. This hypothesis is supported by the $t$ test where the significance is 0.000 (below 0.05) which indicates that this hypothesis is accepted. So that customers have the desire to repurchase Komatsu Forklifts at PT. Bina Pertiwi, customers have the desire to continue using Komatsu Forklifts, and have the desire to buy Komatsu Forklifts at PT. Bina Pertiwi in the future.

\section{Conclusion}

Based on the data processing that has been done, the results obtained are eight hypotheses accepted and three hypotheses rejected. There is a significant relationship between functions on customer satisfaction, usability with customer satisfaction, applications for customer satisfaction, customer support for customer satisfaction, unit features on customer satisfaction, corporate factors on customer satisfaction, customer satisfaction with customer loyalty, and switching costs for customer loyalty. Meanwhile, an insignificant relationship was found between design on customer satisfaction, price on customer satisfaction, and corporate image on customer satisfaction.

\subsection{Recommendation}

Looking at the results of existing research where there are still many limitations to the research conducted by the author, the recommendations that can be submitted by the author are as follows:

- Seeing the limitations regarding the object of research that only takes respondents, namely customers of Komatsu Forklifts at PT. Bina Pertiwi in the East Java area, it is hoped that the next research will use different models and objects to get more general results on the factors that affect customer loyalty.

- Further research is expected to complement the existing variables in this research so that it can further enhance the understanding of the factors that affect customer loyalty, for example, such as adding product quality variables, alternatives of attractiveness, word of mouth or other variables.

- Further research can be developed by linking the factors that affect customer loyalty based on income level, age and gender. Future research can also expand the scope of respondents who will be researched, or carry out their research in a different area from the current research, so that further research is carried out to provide a broad picture of customer loyalty.

\section{References}

Ahmad, T., dan Vays, N. (2011). The Impulse Buying Behavior of consumes for the FMCG Products in Jodhpur. Australian Journal of Basic and Applied Sciences 5(11), 1704-1710. 
Al-hawari, M, A. (2014). Emotional stability and switching barriers in the retail banking context. Managing Service Quality: An International Journal, 24(5), 469-486.

Anderson, R.E., dan Srinivasan, S.S., (2003). E-satisfaction and e-loyalty: a contingency framework. Psychol. Mark. 20 (2), 123-138.

Anderson, C.R., dan Zeithaml, C.P. (1984). Stage of the product life cycle, business strategy, and business performance. Acad. Manag. J. 27 (1), 5-24.

Andrews, L., Drennan, J., dan Russell-Bennett, R. (2012). Linking perceived value of mobile marketing with the experiential consumption of mobile phones. Eur. J. Mark. 46 (3-4), 357-386.

Armistead, C.G. and Clark, G .(1992). Customer Service and Support, Pitman. London

Barnes, James G. (2003). Secrets Of Customer Relationship Management. ANDI. Yogyakarta.

Bates, John E. G., dan Douglas Hoffman. (1999). Managing Services Marketing: Text and Readings.

Beerli, A., Martin, J. dan Quintana, A. (2004). A model of customer loyalty in the retail banking market. European Journal of Marketing, Vol. 38 No. 1, pp. 253-275.

Bhattacherjee, A., dan Premkumar, G. (2004). Understanding changes in belief and attitude toward information technology usage: a theoretical model and longitudinal test. MIS Q. 28 (2), 229-254.

Belanche, D., Casaló, L.V., dan Guinalíu, M. (2012). Website usability, consumer satisfaction and the intention to use a website: the moderating effect of perceived risk. J. Retail. Consum. Serv. 19 (1), $124-132$.

Blanchard, B.S. (1991). The Impact of Integrated Logistic Support on the Total Cost-Effectiveness of a System. International Journal of Physical Distribution \& Logistics Management. Vol. 21, No. 5, pp2326.

Bose, S., dan Rao, V.G. (2011). Perceived benefits of customer loyalty programs: validating the scale in the Indian context. Management \& Marketing Challenges for the Knowledge Society Vol. 6, No. 4, pp. 543-560.

Bansal, H.S., Taylor, S.F., dan James, Y.S. (2005). Migrating to New Service Providers: Toward a Unifying Framework of Cunsumers Switching Behaviors. Journal of the Academy of Marketing Science. Vol 33:96-115

Barnes, James G. (2003). Secrets Of Customer Relationship Management. ANDI. Yogyakarta.

Bennet, J. (1984). Managing to meet usability requirements: establishing and meeting software development goals. In: Bennet, J., Case, D., Sandelin, J., Smith, M. (Eds.), Visual Display Terminals. Prentice-Hall, Englewood Cliffs, NJ, pp. 161-184.

Bevan, N. (2001). International standards for HCI and usability. Int. J. Hum Comput Stud. 55 (4), 533-552.

Buyens, Jim. (2001). Web Database Development. Elex Media Komputindo. Jakarta.

Chen, C-F., dan Tsai, M-H. (2008). Perceived Value, Satisfaction, and Loyalty of TV Travel Product Shopping: Involvement as a Moderator. Journal of Tourism Management. 29:1166-1171.

Claes, Robert. (2003). Effects of Switching Barriers on Satisfaction, Repurchase Intentions and Attitudinal Loyalty, Sweden Commerce. A Managerial Perspective Global Edition. New Jersey: Pearson. Vol. 7. 
Colgate, M. and B. Lang. (2001). Switching Barriers in Consumer Market: An Investigation of the Financial Services Industry. Journal of Consumer Marketing, Vol. 18 No. 4, pp. 332-347.

Dapkevičius, A. \& Melnika, B. (2009). Influence of Price and Quality to Customer Satisfaction: Neuromarketing Approach.

Dwyer, F.R., and J. F. Tanner. (1999). Business Marketing: Connecting Strategy, Relationships and Learning. Boston: McGraw-Hill.

Dehghan, A. dan Shahin, A. (2011). Customer Loyalty Assessment. A Case Study in Maddiran, the Distributor of LG Electronics in Iran. Business Management and Strategy, Vol. 2, No. 1: E2, p.p. 1-23.

Deng, Z., Lu, Y., Wei, K.K., dan Zhang, J. (2010). Understanding customer satisfaction and loyalty: an empirical study of mobile instant messages in China. Int. J. Inf. Manage. 30 (4), 289-300.

Demirgunes, B.K. (2015). Relative importance of perceived value, satisfaction, and perperceived risk on willingness to pay more. International Review of Management and Marketing, Vol. 5, No.4, p.p 211220.

Dick, A.S. dan Basu, K. (1994). Customer Loyalty: Toward an Integrated Conceptual Framework. Journal of the Academy of Marketing Science, 22, 99-113.

Dumas, Joseph S., dan Janice C. Redish. (1994). A Practical Guide to Usability Testing. Ablex, Norwood, NJ.

Dumas, Joseph S., dan Janice, C. Redish. (1999). A Practical Guide to Usability Testing. Revised Edition. Bethesda, USA : Redish \& Associates, Inc.

Durianto, Darmadi., Sugiarto \& Sitinjak, Tony. (2001). Strategi Menaklukkan Pasar Melalui Riset Ekuitas dan Perilaku Merek. Jakarta: Gramedia Pustaka Utama.

Doelhadi, E.M. (2006). Mengukur Tingkat Kepuasan Pelanggan: Perspektif Psikologi Konsumen. Fakultas Psikologi Universitas Airlangga. Surabaya.

Edward, M.., dan Sahadev, L. (2011). Role of switching costs in the service quality, perceived value, customer satisfaction and customer retention linkage. Asia Pacific Journal of Marketing and Logistics, Vol. 23 No. 3, pp. 327-345.

Ene, S., dan Ozkaya, B. (2014). A study on corporate image, customer satisfaction and brand loyalty in the context of retail stores. Asian Social Science, 10(14), 52-66.

Engel, James F. Roger D. Blackwell \& Paul W Miniard. (2006). Perilaku Konsumen, (Alih Bahasa Bidi Janto), Jilid II, Edisi Keenam. Jakrta Barat: Binarupa Aksara.

Fernandes, F. A. P. (2017). Perceived value of buying tourism services through an Online Travel Agency. Master Thesis program Porto University, Portuguese.

Fornell, C. (1992). A National Customer Satisfaction Barometer: The Swedish Experience. Journal of Marketing, Vol. 56.

Gerpott, T.J., Rams, W., Schindler, A. (2001). Customer retention, loyalty, and satisfaction in the German mobile cellular telecommunications market. Telecommun. Policy 25 (4), 249-269.

Ghozali, Imam. (2004). Aplikasi Analisis Multivariate dengan Program SPSS. Semarang : Badan Penerbit Diponegoro. 
Goffin, K. (1999). Customer support: a cross-industry study of distribution channels and strategies. International Journal of Physical Distribution \& Logistics Management, Vol. 29 No. 6, pp. 374-97.

Goffin, K., dan New, C. (2001). CUSTOMER SUPPORT AND NEW PRODUCT DEVELOPMENT-AN EXPLORATORY STUDY. Published in the International Journal of Operations \& Production Management, Vol 21 (3), 2001 pp275-301.

Haenlein, M., Kaplan, A.M. (2012). The impact of unprofitable customer abandonment on current customers' exit, voice, and loyalty intentions: an empirical analysis. J. Serv. Mark. 26 (6), 458-470.

Hair, J. F., Black, W. C., Babin, B. J., Anderson, R. E., dan Tatham, R. L. (2006). Multivariat Data Analysis Sixth Edition. New Jersey: Pearson Prentice Hall.

Ha, Y.W., dan Park, M.C. (2013). Antecedents of customer satisfaction and customer loyalty for emerging devices in the initial market of Korea: an equity framework. Psychol. Mark. 30, 676-689.

Han, S. H., Yun, M. H., Kwahk, J., \& Hong, S. W. (2001). Usability of consumer electronic products. International Journal of Industrial Ergonomics, 28(3-4), 143-151.

Hansemark, Albinsson. (2004). Customer satisfaction and retention: the experiences of individual employees. Managing Service Quality: An International Journal, Vol. 14 Iss: 1, pp.40 57.

ISO : ISO 9241-11. (1998). Ergonomic Requirements for OfficeWork With Visual Display Terminals (VDT). Part 11: Guidance in Usability. International Standards Organization, London.

Jasfar, Farida. (2005). Manajemen Jasa Pendekatan Terpadu. Ghalia Indonesia, Bogor.

Jones, M. A., Mothersbaugh, D. L., dan Beatty. S. E. (2000). Switching Barriers and Repurchase Intentions in Service. Journal of Retailing, Volume 76(2) pp. 259-274, ISSN: 0022-4359.

Jung, W., Kwon, Y. (2015). Differences between LTE and 3G service customers: business and policy implications. Telematics Inform. 32 (4), 667-680.

Jahanshahi, A. A., Gashti, M. A. H., Mirdamadi, S. A., Nawaser, K., dan Khaksar, S. M. S. (2011). Study the effects of customer service and product quality on customer satisfaction and loyalty. International Journal of Humanities and Social Science, 1(7), 253-260.

Jones, M. A., and J. Suh. (2000). Transaction-specific satisfaction and overall satisfaction: An empirical analysis. Journal of Services Marketing 14 (2): 147-159.

Jones, M.A., Mothersbaugh, D.L., Beatty, S.E. (2000). Switching barriers and repurchase intentions in services. J. Retail. 76, 259-274.

Julander, C-R., Soderlund, M. (2003). Effects of Switching Barriers on Satisfaction, Repurchase Intentions and Attitudinal Loyalty. SSE/EFI Working Paper Series in Business Administration. No.2003:1.

Julander, C.R., Ragnar, Soderberg., dan Magner, Soderlund. (2003). Effects of Switching Barriers on Satisfaction, Repurchase Intentions and Attitudinal Loyalty. Stockholm School of Economics.

Kim, H.S., dan Yoon, C.H. (2004). Determinants of subscriber churn and customer loyalty in the Korean mobile telephony market. Telecommun. Policy 28 (9), 751-765.

Kim, M.K., Park, J.H., Paik, J.H. (2014). Relationship between service-related activities, service capability and market diffusion: case of WiBro. ETRI J. 36 (3), 490-497. 
Kim, M., Chang, Y., Park, M.-C., \& Lee, J. (2015). The effects of service interactivity on the satisfaction and the loyalty of smartphone users. Telematics and Informatics, 32(4), 949-960.

Kim, M-K., Wong, S. F., Chang, Y., dan Park, J-H. (2016). Determinants of customer loyalty in the Korean smartphone market: Moderating effects of usage characteristics. Telematics and Informatics 33 (2016) 936-949.

Klemperer, P. (1995). Competition When Consumers have Switching Costs: An Overview with Applications to Industrial Organization, Macroeconomics, and International Trade. The Review of Economic Studies, Vol. 62, pp. 515-539.

Knecht, T., Lezinski, R. and Weber, F.A. (1993). Making Profits After the Sale, The McKinsey Quarterly, Winter, No. 4, pp79-86.

Kotler P., Hayes, Thomas, Bloom Paul N. (2002). Marketing Professional Service, Prentice Hall International Press.

Kotler, Philip and Gary Amstrong. (2012). Principles Of Marketing, Global Edition, 14 Edition, Pearson Education.

Kotler, Philip. (2003). Manajemen Pemasaran. Edisi kesebelas, Indeks kelompok Gramedia: Jakarta.

Lai, F., Griffin, M., Babin, B.J. (2009). How quality, value, image, and satisfaction create loyalty at a Chinese telecom. J. Bus. Res. 62 (10), 980-986.

Lee, D., Moon, J., Kim, Y.J., Mun, Y.Y. (2015). Antecedents and consequences of mobile phone usability: linking simplicity and interactivity to satisfaction, trust, and brand loyalty. Inf. Manage. 52 (3), 295304.

LeBlanc, G. and Nguyen, N. (1996). Cues used by customers evaluating corporate image in service firms, an empirical study in financial institutions, International Journal of Service. Industry Management, Vol. 7 No. 2, pp. 44-56.

Lee, J., J. Lee., and L. Feick. (2001). The Impact of Switching Costs on the Customer Satisfaction-loyalty Link: Mobile Phone Service in France. Journal of Services Marketing, Vol. 15 No. 1, pp. 35-48.

Machfoedz, Mahmud. (2010). Komunikasi Pemasaran Modern. Cetakan Pertama. Cakra Ilmu: Yogyakarta.

Margono. (2010). Metodologi Penelitian Pendidikan. Jakarta: Rineka Cipta

Martenson, R. (2007). Corporate brand image, satisfaction and store loyalty: A study of the store as a brand, store brands and manufacturer brands. International Journal of Retail \& Distribution Management, 35(7), 544-555.

Mittal, V., Kamakura, W.A. (2001). Satisfaction, repurchase intent, and repurchase behavior: investigating the moderating effect of customer characteristics. J. Mark. Res. 38 (1), 131-142.

Mowen, J.C., dan Minor, M. (2002). Perilaku Konsumen. Jakarta: Erlangga.

Mowen, John., dan Michael, Minor. (2008). Consumer Behavior 6ed. New Jersey : Prentice-Hall,Inc.

Nielsen, J. (2012). Usability 101: An Introduction to Usability. Nielsen Norman Group, (pp. 1-6).

Oesman, Y, M. (2010). Sukses Mengelola Marketing Mix, CRM, Custumer Value dan Custumer Dependency. Cetakan pertama. Bandung : Alfabeta. 
Oetarjo, M., \& Prastyo, H. E. (2017). Pengaruh Kualitas Produk Dan Kualitas Layanan Terhadap Loyalitas Pelanggan Pt. Roman Ceramic International Di Mojokerto. Jurnal Bisnis, Manajemen \& Perbankan, 35-51.

Oghuma, A.P., Libaque-Saenz, C.F., Wong, S.F., Chang, Y. (2016). An expectation-confirmation model of continuance intention to use mobile instant messaging. Telematics Inform. 33 (1), 34-47.

Oliver, R.L. (1981). Measurement and evaluation of satisfaction processes in retail settings. Journal of Retailing 57(3), 25-48.

Oliver, Richard 1. (1997). Satisfaction: A Behavioral Perpective On The Consumer, The McGraw-Hill Companise, Inc : New York.

Park, C. (2004). Efficient or enjoyable, Consumer values of eating-out and fast food restaurant consumption in Korea. International Journal of Hospitality Management. 23(1), March: 87-94.

Paurav, Shukla. (2004). Effect of Product Usages, Satisfaction and Invelovement on Brand Switching Behavior. Asia Pacific Journal of marketing and Logistics. Vol 16. No 4. Hal. 23-82.

Ping, R.A. Jr. (1993). The effects of satisfaction and structural constraints on retailer exiting, voice, loyalty, opportunism, and neglect. Journal of Retailing, Vol. 69 No. 3, Fall, pp. 321-49.

Priyanto. (2010). Teknik Mudah dan Cepat Melakukan Analisis Data Penelitian Dengan SPSS. Yogyakarta. Gava Media.

Pressman, R. S., dan Maxim, Bruce. (2014). Software Engineering: A Practitioner's Approach. Singapore: McGraw-Hill Education. 8 Edition.

Ranaweera, C. and J. Prabhu. (2003). The Influence of Satisfaction, Trust and Switching Barriers on Customer Retention in a Continuous Purchasing Setting. International Journal of Service Industry Management. Readings. Orlando: The Dryden Press Harcourt Brace College Publisher.

Reichheld, F.F., Teal, T. (2001). The Loyalty Effect: The Hidden Force Behind Growth, Profits, and Lasting Value. Harvard Business Press.

Rusbult, C.E. (1980). Commitment and satisfaction in romantic associations: a test of the investment model. Journal of Experimental and Social Psychology, No. 16, pp. 172-86.

Santouridis, C., dan Trivellas, P. (2010). Investigating the impact of service quality and customer satisfaction on customer loyalty in mobile telephony in Greece. The TQM Journal Vol. 22 No. 3, 2010 pp. 330343.

Sekaran, U. (2003). Research Methods for Business : A Skill Building Approach 2nd Edition. New York: John Wiley and Son.Sekaran,U. (2006). Research Methods for Business. Jakarta: Salemba Empat

Sharma, N. dan Patterson, P. (2000). Switching costs, alternative attractiveness and experience as moderators of relationship commitment in professional, consumer services. International Journal of Service Industry Management, Vol. 11 No. 5, pp. 470-490.

Shackel, B. (1984). The concept of usability. In: Bennet, J., Case, D., Sandelin, J., Smith, M. (Eds.), Visual Display Terminals. Prentice-Hall, Englewood Cliffs, NJ, pp. 45-87.

Stokes, Jane. (2007). How To Do Media \& Cultural Studies, London : Sage Publications.

Siu, N. Y. M., and D. K. H. Chow. (2003). Service quality in grocery retailing: The study of a Japanese 
supermarket in Hong Kong. Journal of International Consumer Marketing 16 (1): 71-87.

S. Supriyanto dan Ernawati. (2010). Judul: Pemasaran Industri Jasa Kesehatan. Penerbit CV Andi Offset: Yogyakarta.

Sunter, C. (1993). In Van Heerden, Cornelius H. dan Puth, Gustav. 1995. Factors that Determine the Corporate Image of South African Banking Institutions. International Journal of Bank Marketing. Vol. 13. No. 3 p. $12-17$.

Sweeney, J.C., Soutar, G.N. (2001). Consumer perceived value: the development of a multiple item scale. J. Retail. 77, 203-220.

Syamrilaode. (2011). Kelebihan dan Kelemahan Metode Kuantitatif. Diunduh pada 14 Juni 2020 dari World Wide Web: http://id.shvoong.com/writingand- speaking/presenting/2131807-kelebihan-dankelemahanmetode-kuantitatif.

Tang, W. W. (2007). Impact of corporate image and corporate reputation on customer loyalty: A review. Management Science and Engineering, 1(2), 57-62.

Tan, W.K., dan Sie, M.S. (2015). The impact of personal innovativeness on product aesthetics and selfconnection with brand: a case study of mobile phone users. Behav. Inf. Technol. 34 (3), 316-325.

Tjiptono, Fandy. (2014). Pemasaran Jasa - Prinsip, Penerapan, dan Penelitian, Andi Offset, Yogyakarta.

Trif, S.M. (2013). The influence of overall satisfaction and trust on customer loyalty. Management \& Marketing, 8(1), 109.

Tseng, F.-M., Lo, H.-Y. (2011). Antecedents of consumers' intentions to upgrade their mobile phones. Telecommun. Policy 35 (1), 74-86.

Turban Effraim, Leidner, McLean, Wetherbe. (2008). Information Technology for Management.

Turban. E., King. D., Lee. J. K., Liang, T. P., and Turban, D.C. (2015). Electronic Commerce: A Managerial and Social Networks Perspective. 8th Ed. Springer.

Verriana, R. I., \& Anshori, M. Y. (2017). Pengaruh Kualitas Layanan (Service Quality) Terhadap Loyalitas Melalui Kepuasan Pada Mahasiswa Universitas Nu Surabaya. Accounting And Management Journal, 63-79.

Wei wei, Tang. (2007). Impact of corporate image and corporate reputation on customer loyalty. Jurnal management science \& engineering, Vol 1 No.2 December 2007.

Wijaya, Tony. (2009). Analisis Structural Equation Modeling Menggunakan AMOS. Jogjakarta: Universitas Atmajaya Jogjakarta.

Xu, C., Peak, D., dan Prybutok, V. (2015). A customer value, satisfaction, and loyalty perspective of mobile application recommendations. Decision Support Systems, 79, 171-183.

Yang, Z. and Peterson, R. (2004), "Customer perceived value, satisfaction, and loyalty: the role of switching costs", Psychology \& Marketing, Vol. 21 No. 10, pp. 799-822.

Yen, Y. X., \& Horng, D. J. (2009). Effects of satisfaction, trust and alternative attractiveness on switching intentions in industrial customers. International Journal of Management and Enterprise Development, $8(1), 82-101$. 
Yesawich, P.C. (2004). Consistent pricing will give customers booking confidence, Hotel and Motel Management 219(4), 18-29.

Yusoff, M. (1995), Konsep Asas Periklanan. Malaysia: Dewan Bahasa dan Pustaka.

Yurchisin, J., Park, J., dan O'Brien, M. (2010). Effects of Ideal Image Congruence and Organizational Commitment on Employee Intention to Leave. Journal of Retailing and Cosumer Services. Vol 17: 406-414

Zhu, B., Kim, T.W., Kim, S.W. (2011). A study on formulating the classification model for smartphone's satisfaction factors. Inf. Syst. Rev. 13 (3), 47-63. 